\title{
Effect of Apocynin on Testicular Ischemia/Reperfusion Injury in Male Albino Rats
}

\author{
NEHAL M. GABR, M.Sc.; ROMYSAA A. ELSHRBINY, M.D.; GHADA M. ESMAIL, M.D. and \\ HOSSAM EL-DEEN M. ABODA, M.D.
}

The Department of Physiology, Faculty of Medicine, Tanta University

\begin{abstract}
Background: Apocynin, obtained from the roots of the Apocynum cannabinum plant, is a substance that has the effect of a NOX inhibitor. Apocynin (4-hydroxy-3- methoxyacetophenone) plays a role in the production of superoxide inhibitors. Many pervious studies demonstrated the positive effects of apocynin on renal Ischemia Reperfusion (I/R) in a rat model.
\end{abstract}

Aim of Study: The aim of this work is to study the effect of apocynin on testicular ischemia/reperfusion injury in male albino rats.

Material and Methods: The present work was carried on 30 male albino rats. The rats were divided into three groups, (10 rats for each). Sham operated group (Group I): Delivery of the left testis without twisting and the testis was relocated into the scrotum. Ischemia/reperfusion group (Group II): Testicular torsion was done by rotating the left testis $720^{\circ}$ in anticlockwise direction, these rats were injected intraperitoneally by a single dose of $10 \mathrm{ml}$ normal saline solution. Apocynin treated group (Group III): The same surgical procedure was done as in Group II; these rats were injected intraperitoneally by a single dose of apocynin at a dose of 20 $\mathrm{mg} / \mathrm{Kg} 1 / 2$ an hour before the detorsion. At the end of the experiment, the animals were anesthetized, then the animals were sacrificed by cervical decapitation. The blood samples were collected.

Results: The results of the present work revealed that the 4 hours torsion group showed significant increase in testicular malondialdehyde, serum FSH and LH and multiple apoptotic cells showed by immunohistochemical examination of testicular caspase-3, however it produces significant decrease in testicular GPX level and serum free testosterone level when these results compared to sham operated group, these results were confirmed by histopathological examination which showed thick basement membrane, loss of cohesions of spermatocytes, congested interstitial vessels, oedema, sequestration of spermatocytes and spermatogonia in lumen of tubule and separation of basement membrane. The apocynin treated torsion detorsion group showed significant decrease in testicular malondialdehyde, serum FSH, LH and less apoptotic cells showed by immunohistochemical examination of testic-

Correspondence to: Dr. Nehal M. Gabr, The Department of Physiology, Faculty of Medicine, Tanta University ular caspase-3, however it produce significant increase in testicular GPX level and serum free testosterone level when these results were compared to torsion detorsion group, these results were confirmed by histopathological examination which showed mild thickening of basement membrane and mild loss of cohesion of spermatogenic cells. Interstitial tissue showed mild congestion of vessels with minimal oedema.

Conclusion: We concluded that there is a significant role of Apocynin on testicular ischemia/reperfusion shown from its effect on MDA, GPX, caspase-3, testosterone, serum FSH, $\mathrm{LH}$ in addition to its role in improvement of histopathological picture.

Key Words: Apocynin - Testicular ischemia/reperfusion $M D A-G P X-$ Testosterone - Serum FSH - LH.

\section{Introduction}

TESTICULAR torsion is one of the most common urological emergencies observed in children. The annual incidence is $4.5 \%$ in 100,000 males aged 1-25 years [1]. This condition may cause ischemia and ultimately loss of the testis in short time if an accurate diagnosis is not made and not treated appropriately [1]. Testicular damage varies depending on the grade and duration of the torsion [2]

Production and releasing of Reactive Oxygen Species (ROS) by inflammatory cells, endothelial cells, platelets, injured cells, and cell debris, via many enzymatic mechanisms play an important role on the damage caused by torsion. This damaged incurred with reperfusion may result in irreversible damage $[3,4]$. Although reperfusion is essential for the survival of ischemic tissue, there is evidence that reperfusion itself causes additional cellular injury [5] . NADPH-oxidase (NOX) is a major enzyme that uses NADPH to generate superoxide, initial ROS molecule, from oxygen [6]

Apocynin, obtained from the roots of the Apocynum cannabinum plant, is a substance that has the effect of a NOX inhibitor. Apocynin (4-hydroxy- 
3-methoxyacetophenone) plays a role in the production of superoxide inhibitors. Many pervious studies demonstrated the positive effects of apocynin on renal Ischemia Reperfusion (I/R) in a rat model [7]

It was observed that apocynin strengthens antioxidant defensive systems and enhances the reduced glutathione (GSH) and it limits cellular stress triggered by ischemia [8]. Moreover, it was revealed that in the ischemic cerebral cortex, apocynin decreases GSH consumption, hydrogen peroxide formation $\left(\mathrm{H}_{2} \mathrm{O}_{2}\right)$, and DNA fragmentation [9] .

The aim of this work is to study the effect of apocynin on testicular ischemia/reperfusion injury in male albino rats.

\section{Material and Methods}

\section{Animals:}

The present work was carried out on 30 male adult albino rats of local strain weighing (250$290 \mathrm{gm}$ ). The rats were housed in isolated animal cages, five in each cage, in a standard Animal Laboratory Room in Faculty of Medicine Tanta University and had free access to water and food ad libtium all over the period of the work and were kept at room temperature. All procedures were done according to the ethical committee of Tanta University. The work was done from April 2017 to Nov. 2018.

\section{Chemicals:}

Apocynin preparation: Apocynin was obtained from Sigma Aldrish as a powder dissolved by addition of normal saline.

Study design:

Rats were divided into three main groups: Each consisting of 10 animals.

1- Sham operated group (Group I): Delivery of the left testis without twisting the testicle was done then relocated into the scrotum.

2- I/R group (Group II): Testicular torsion was done by rotating the left testis $720^{\circ}$ anti clockwise direction ( 2 times around the longitudinal axis of the spermatic cord) in an anticlockwise direction, the torsion was maintained by fixing the testis in the scrotum with a $6 / 0$ silk suture and the incision was closed. The rats of this group were underwent left testicular torsion (4 hours) and received a single dose of $10 \mathrm{ml} / \mathrm{Kg}$ $0.9 \%$ normal saline solution intraperitoneally given at the 210 th $\mathrm{min}$ of ischemia (1/2 an hour before the detorsion) then underwent detorsion for one hour [7].

3- Apocynin treated group (Group III): The same surgical procedure was done as in Group II, in addition, these rats were injected intraperitoneally by a single dose of apocynin at a dose of $20 \mathrm{mg} / \mathrm{Kg}$ dissolved in $10 \mathrm{ml} / \mathrm{kg}$ normal saline $1 / 2$ an hour before the detorsion [7] .

\section{Sample collection and analysis:}

At the end of the experimental period, all rats were anaesthetized by intraperitoneal injection of pentobarbital $(50 \mathrm{mg} / \mathrm{kg})$ [10] and blood samples were obtained by decapitation of all animals then serum was separated by centrifugation at 3000rpm for 10 minutes and transferred into clean storage tubes.

Serum samples were used to measure free testosterone level according to the method of Morley et al., (2002) [11], FSH level according to the method described by Gay et al., (1970) [12], and $\mathrm{LH}$ according to the method of Haavisto et al., (1993) [13]

Part of testis will be homogenized in ice-cold sodium potassium phosphate buffer ( $\mathrm{pH}$ 7.4), centrifuged at $3000 \mathrm{rpm}$ at for $10 \mathrm{~min}$ and stored at $-80^{\circ} \mathrm{C}$ for analysis of Malondialdehyde (MDA) according to the method of Ohkawa et al., (1979) [14], Glutathione Peroxidase (GPX) according to the method of Pagalia and Valentine, (1967) [15] Immunohistochemical study for caspase-3 activity according to the method of Kim et al., (2007) [16] and histopathological examination of testicular tissue was done.

\section{Statistical analysis:}

The data were shown as the mean \pm standard deviation. Data from the study were analyzed using by one-way analysis of variance (ANOVA) followed by Tukey's test to assess the significance. The $p<0.05$ were considered as statistically significant. Using SPSS for windows (Version 23.0).

\section{Results}

Effect of the apocynin on testicular MDA and GPX:

Fig. (1), showed that MDA levels significantly increase in testicular tissue with concomitant decrease of testicular GPX levels in I/R group as compared to normal sham operated group. As regard, apocynin -treated group, MDA levels significantly decreased in testicular tissue with concomitant increase of testicular GPX levels as compared to I/R group. However, these levels were 
non-significantly changed as compared to the normal sham operated group. These parameters returned to the normal level as compared to the normal sham operated group.

Effect of the apocynin on serum free testosterone, FSH \& LH levels:

As shown in Fig. (2), there was significant decrease in serum level of free testosterone while significant increase in serum levels of FSH and LH in I/R group as compared to the normal sham operated group. However, apocynin treated group significantly increased serum level of free testosterone while significant decrease in serum levels

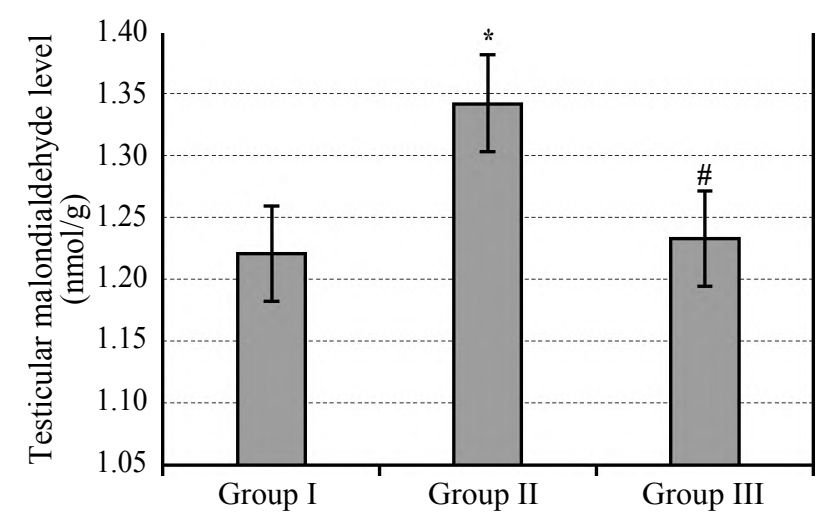

of FSH and LH as compared to I/R group. But, these levels were non-significantly as compared to the normal sham operated group. These parameters returned to the normal level as compared to the normal sham operated group.

Effect of the apocynin on testicular caspase-3 activity:

As presented in Fig. (3) immunohistochemical staining of testicular section to caspase-3 from rats of this group showed no apoptotic cells in sham operated group. While in Fig. (4) multiple apoptotic cells in I/R group and in Fig. (5) decrease number of them in apocynin treated group).

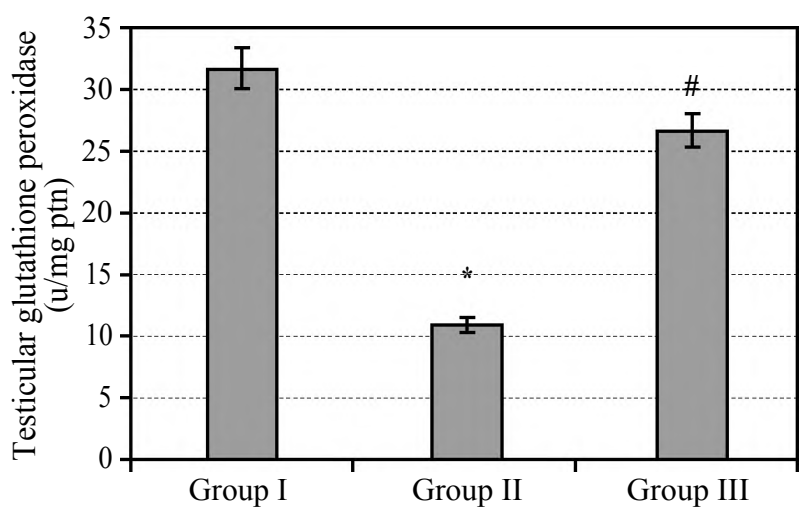

Fig. (1): Effect of the apocynin on testicular MDA and GPX.

Data are given as mean $\pm \mathrm{SD}$.

*: $p<0.05$ vs. normal sham operated group.

$\#: p<0.05$ vs. I/R group.
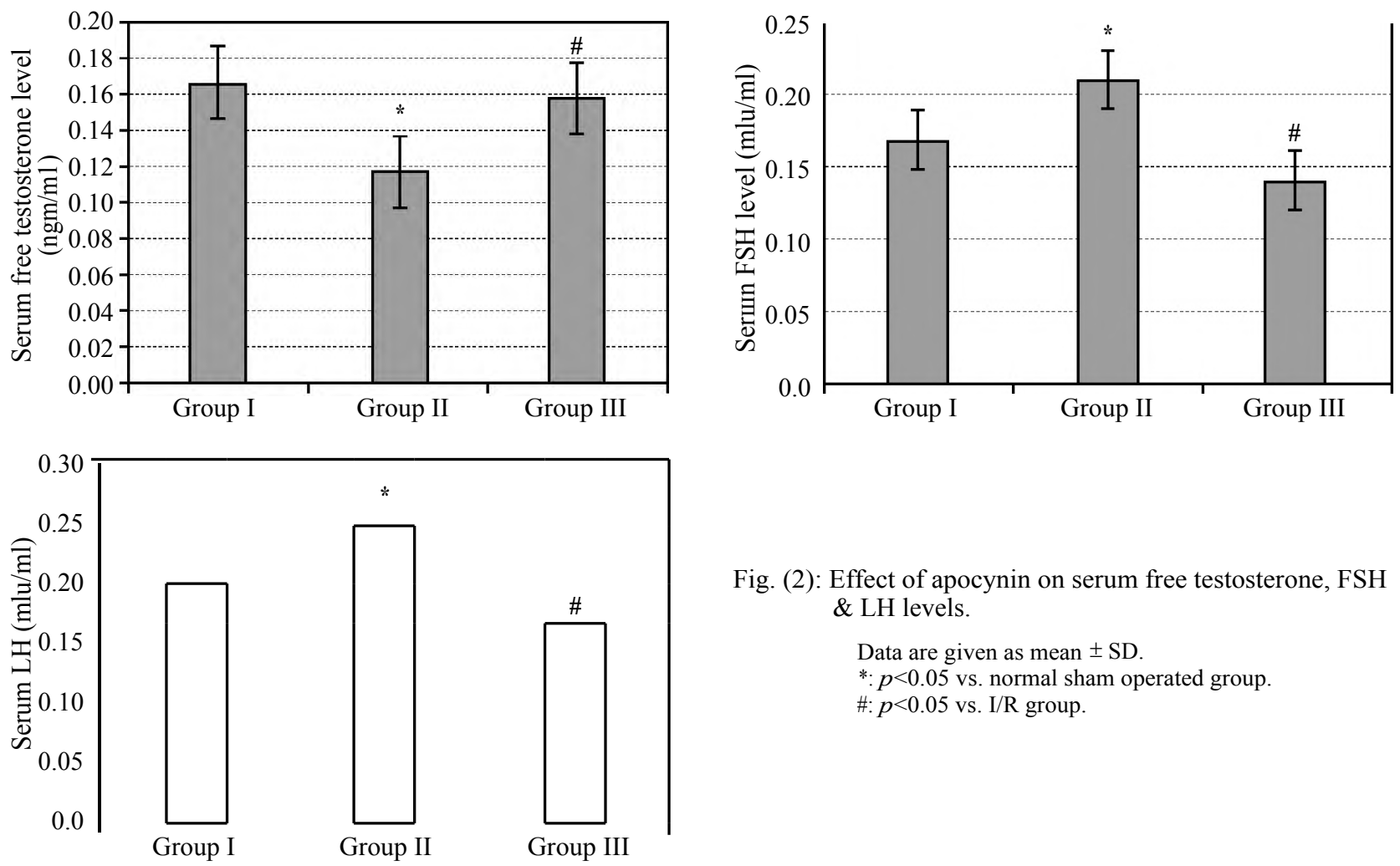

Fig. (2): Effect of apocynin on serum free testosterone, FSH \& LH levels.

Data are given as mean $\pm \mathrm{SD}$

$*: p<0.05$ vs. normal sham operated group.

$\#: p<0.05$ vs. I/R group. 
Effect of the apocynin on testicular caspase-3 activity:

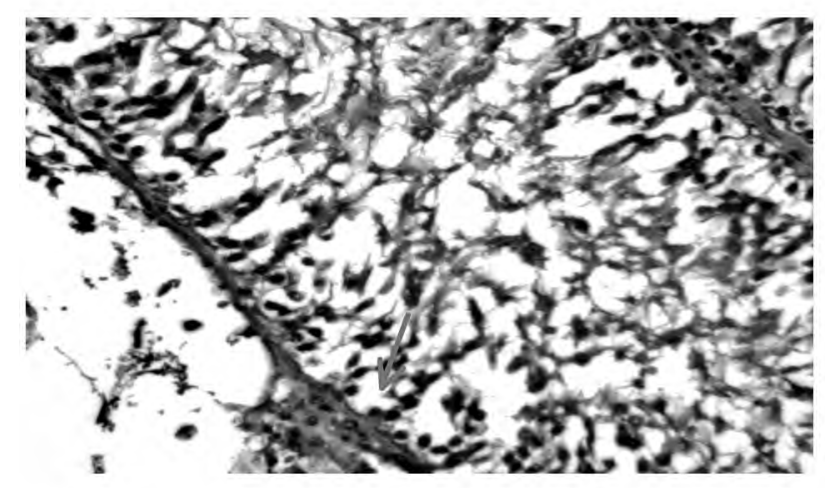

Fig. (3): Sham operated group. Testicular section was negative for caspase-3 stain. Showing no apoptotic cells (Immunoperoxidase $\mathrm{X} 400$ ).

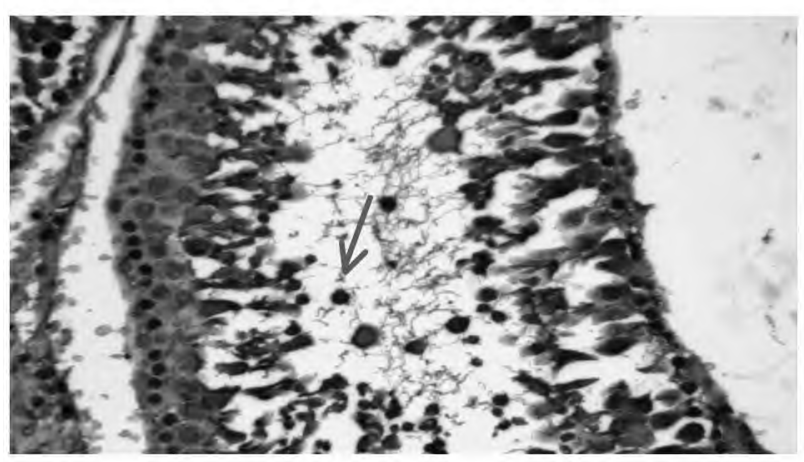

Fig. (4): I/R group. Testicular section was positive for caspase3 stain. Showing many apoptotic cells. (Immunoperoxidase X400).

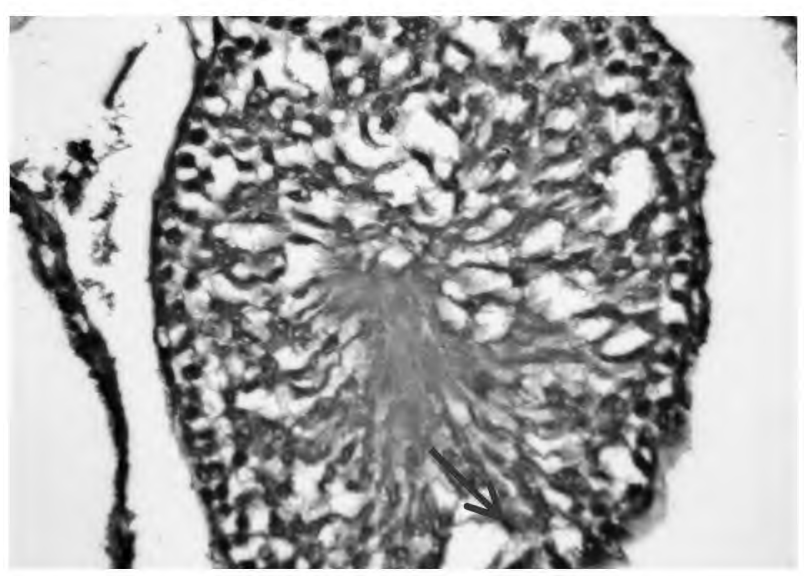

Fig. (5): Apocynin treated group. Testicular section was weak positive for caspase-3 stain. Showing few apoptotic cells (Immunoperoxidase X400) .

\section{Testicular histopathology:}

Testicular section showed thick basement membrane, loss of cohesions of spermatocytes, congested interstitial vessels, oedema, sequestration of spermatocytes and spermatogonia in lumen of tubule and separation of basement membrane in I/R group as showed in Fig. (7). However, mild thickening of basement membrane and mild loss of cohesion of spermatogenic cells. Interstitial tissue showed mild congestion of vessels with minimal oedema in apocynin treated group as showed in Fig. (8).

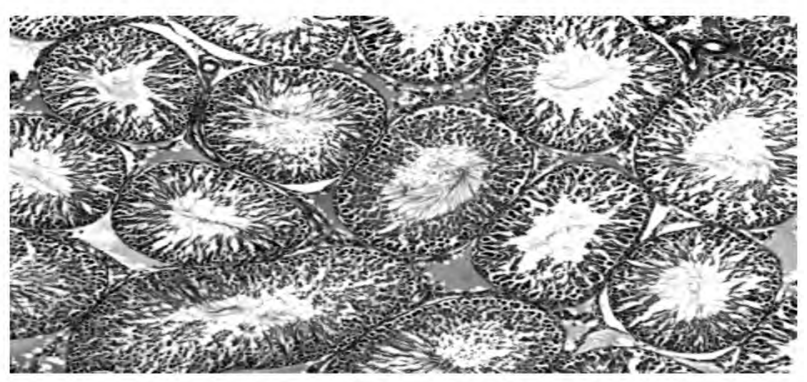

Fig. (6): Sham operated group. Normal testicular architecture with slightly congested interstial vessels. ( $\mathrm{H} \& \mathrm{E}$ X100).

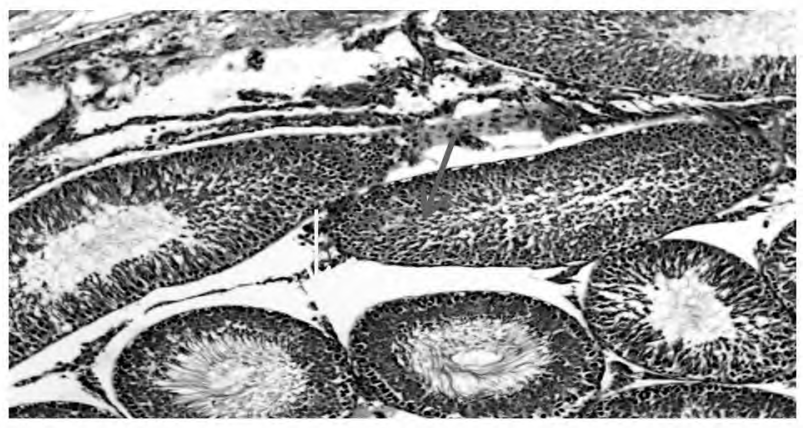

Fig. (7): I/R group. Testicular section showing central necrosis of the seminiferous tubules (blue arrow) and interstitial edema (red arrow) (H \& E X100).

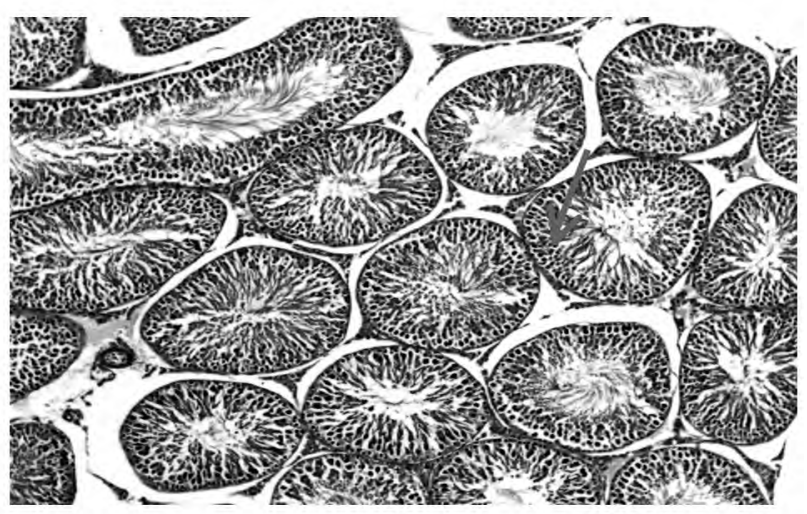

Fig. (8): Apocynin treated group. Normal testicular architecture, slightly congested interstitial vessels and slight interstitial edema (H \& E X100).

\section{Discussion}

The results of the present work revealed that in $\mathrm{I} / \mathrm{R}$ group, there was evidence of oxidative stress in testicular tissue. Also, there was evidence of apoptosis of the testicular tissue manifested by significant increase of testicular caspase-3 levels. In addition, there was significant impairment of endocrinal function of testes and These results were confirmed by histopathological findings of the testicular tissue. The result of the present work 
showed the efficacy of apocynin in preventing injury of testis induced by ischemia/reperfusion in male albino rats.

The results of the present work demonstrated that significant increase in testicular MDA level in I/R group agrees with the study of (Chan) [17] who showed increase in MDA level after ischemia. The significant increase in testicular MDA level in $\mathrm{I} / \mathrm{R}$ group could be explained by the initial obstruction of spermatic cord venous blood flow caused by testicular torsion with secondary edema and hemorrhage, then edema results in ischemia, further arterial obstruction leads to damage and production of free radicals [18]

Another mechanism is reported by Al-Omar et al., [19] who stated that ischemia affect the nervous supply of tissues causing more necrosis and production of lipid peroxides that arise from damaged cells.

Apocynin treatment showed significant decrease in MDA level. These results can be explained by the effect of apocynin that prevents cell damage, lipid peroxidation and may reduce the production of ROS as proved by the results of this study. These results was agreed by Altantis et al., [7] who showed that apocynin inhibits the production of MDA which is a major indicator of oxidative stress, which increases due to lipid peroxidation, which is one of the harmful consequences of $I / R$ injury.

Ozdemir et al., (2006) [20] also showed that, apocynin can reduce I/R cell damage that rapidly causes cellular injury associated with lipid peroxidation. Furthermore, Yayi et al., [21] also stated that apocynin reduced MDA level that shows significant increase in I/R injury suggesting that oxidative balance was disrupted after I/R and improved by apocynin administration.

In addition, Sahna et al., [22] showed that, apocynin administration inhibit lipid peroxidation which is the main pathway of oxidative stress, regardless of the source of free radicals, by blocking of this pathway and may be an effective strategy to prevent ROS-mediated testicular damage.

The results of the present work showed significant reduction in GPX level which reversed by apocynin treatment. The reduction of GPX by I/R may be due to increase MPO levels that may increase free radicals. Also, the mechanism by which apocynin increase GPX may be due to reduction of lipid peroxidation and oxidative stress which may reduce active free radicals. MPO has been essential for the mechanism of action of apocynin.
Exposure to MPO induces apocynin dimer formation and inhibition of the oxidase (Carolina et al., 2012) [23]

Gezginci-Oktayoglu et al., [24] explained that, glutathione peroxidase plays primary role in minimizing the oxidative stress that increased by apocynin treatment. Moreover, Altantis et al., [7] showed significant increase in GPX activity in I/R group treated by apocynin. Furthermore, Van Haaften et al., [25] proved that, apocynin increased GPX which is important component of the protective mechanism of the cell against lipid peroxidation and oxidative stress, which occur during I/R injury and GPX convert hydrogen peroxide to water thus, they prevent the formation of more reactive-free radicals.

In addition, Sener et al., [26] suggested that apocynin increase the depleted glutathione peroxidase in ischemic renal tissue.

The results of the present work showed multiple apoptotic figures by immunohistochemical examination in torsion group as compared to the control normal group that indicates increase in caspase level after ischemia.

Apoptosis, or programmed cell death, is a physiological process of selected cell deletion [27]. It plays a critical role in the survival of multicellular organisms by getting rid of damaged or infected cells that may interferes with normal function [28]

As an antagonist of cell proliferation, apoptosis contributes to keeping the cell number of testicular tissue and helps to remove damaged cells, but excessive apoptosis could cause destruction of male reproductive function (Shaha et al., [29] .

Apoptosis can be regulated by many modulators, including some ions, genes, proteins as caspases [30]. Among of these regulators, member of the caspase family of aspartic acid-directed cysteine proteases, leads to the loss of cellular structure and function and eventually results in apoptotic cell death (Gao et al., 2013) [31].

In mammalian cells, the caspase family contains at least 14 enzymes, which can be mainly divided into two categories, initiator caspases and executioner caspases depending on where they function in the apoptotic cascade (Parrish et al., [32]

Initiator caspases include caspase-2, -8, -9 and10 (Kitazumi and Tsukahara, [33]. Once activated, they cleave and activate the executioner caspases which consist of caspases-3 (Akanda et al., 2017) [34]. The activated executioner caspases then cleave 
their respective substrates to cause demolition of the cell [33].

Briefly the caspase activation is regulated through either extrinsic pathway (death receptor pathway) or intrinsic pathway (mitochondrial pathway) (Pop and Salvesen, 2009) [35]. Hyman and Yuan, [36] showed increase in caspase level after ischemia.Kirkland et al., [37] also stated that the increase of caspase- 3 is due to ischemia itself which damages tissues directly forming apoptotic points. Moreover, selective caspase-3 inhibitor affords protection of tissues against ischemic insult.

Jover et al., [38] added that after ischemic insult, there is an overproduction of ROS due to inactivation of antioxidant enzymes and consumption of antioxidants, these oxidants causes further tissue damage and is thought to be important trigger molecule for apoptosis after ischemic stroke which damages cell and activates more caspases. There is increasing evidence suggested that oxidative stress and apoptosis are closely linked phenomena in the pathophysiology of ischemic stroke (Mergenthaler et al., [39].

The results of the present work showed less apoptotic cells in testicular tissues in apocynin treated group.

These results are in accordance with those observed by (Fu et al., [40] who reported that, apocynin decreases oxidative stress, apoptosis, inflammation following spinal cord ischemiareperfusion injury in rats. Also, Liu et al., [41] reported that, apocynin interfered with cobalt chloride induced pheochromocytoma cell apoptosis by inhibiting caspase- 3 pathway.

In addition, Gimenes et al., [42] proved that, apocynin ameliorates pressure overload-induced cardiac remodeling by reducing collagen deposition, and inhibition of apoptosis in cardiomyocyte by suppressing the excessive production of Reactive Oxygen Species (ROS).

Our results also showed significant decrease in serum free testosterone level in torsion group. This result agrees with the study of (Chatani, [43] who showed decrease in testosterone level after ischemia. This is because leydig cells lost the capacity for steroidogenesis and are compromised prior to germ cell loss after torsion [44].

Another mechanism reported by Aktas et al., [45] who proved that, the decrease in serum free testosterone level was caused by decrease in blood flow to testicular cells which caused necrosis and apoptosis including the interstitial leydig cells. Our biochemical results were confirmed by immunohistochemical results of caspase which showed multiple apoptotic figures that affect interstitial leydig cells.

The mechanism that can explain the increase of testosterone serum levels by apocynin administration is that apocynin enhances the defense antioxidant system and reduces oxidative stress and hence decreases the oxidative damage on cellular processes and steroidogenesis in leydig cells (Aitken and Roman., 2008) [46].

Our results also showed significant increase in the serum levels of both FSH and LH level in torsion group.

It is well established that FSH and LH are essential for the maintenance of spermatogenesis. The process of spermatogenesis is regulated by gonadotropin-releasing hormone $(\mathrm{GnRH})$ to produce FSH and LH that act on the testis to regulate spermatogenic potential. The binding of $\mathrm{LH}$ to its receptors on the surface of leydig cells stimulates the production of testosterone that diffuses into the seminiferous tubules. Within the germinal epithelium of seminiferous tubules, testosterone and FSH receptors are found only in Sertoli cells; hence, these cells regulate spermatogenesis. FSH plays essential role in the maturation of germ cells and for the initiation of spermatogenesis [47]

$\mathrm{LH}, \mathrm{FSH}$ secretion is regulated predominantly by serum testosterone via its negative feedback to the pituitary. The findings of the present work have confirmed the results of Ahmed et al., [48], they reported that FSH level was significantly elevated in I/R group compared to control group this rise could be attributed to the defective spermatogenesis in $\mathrm{I} / \mathrm{R}$ group.

Also, O'Shaughnessy et al., [49] observed that the elevation of FSH level due to negative feedback mechanism of decreased testosterone level. Similarly, Gong et al., [50], reported that with decrease serum androgen concentration, a progressive rise of plasma LH levels was noticed.

\section{Conclusion:}

From these results, we concluded that there is a significant role of Apocynin on testicular ischemia/reperfusion shown from its effect on MDA, GPX, caspase-3, testosterone, serum FSH, LH in addition to its role in improvement of histopathological picture. Also, these findings highlight that Apocynin treatment can be used beside surgical correction as a novel therapeutic approach 
in ischemia/reperfusion of the testis to ameliorate its injurious effect, and to be an alternative therapy instead of removal of ipsilateral testicular torsion. However, introducing Apocynin for this purpose would require additional basic research in different species, including human being.

\section{References}

1- POGORELÍ C.Z., MRKLÍ C.I. and JURÍ C.I.: Testicular torsion in the inguinal canal in children. J. Pediatr. Urol., 9: 793-7, 2013.

2- GÖKÇE A., OKTAR S., KOC A., GONENCI R., YALCINKAYA F., et al.: Protective effect of thymoquinone in experimental testicular torsion. Urologia internationalis; 85 (4): 461-5, 2010.

3- De GROOT H. and RAUEN U.: Ischemia-reperfusion injury: Processes in pathogenetic networks. In Transplantation Proceedings, 39 (2): 481-4, 2007.

4- KENNEDY S.E. and ERLICH J.H.: Murine renal ischemia reperfusion injury. Nephrology, 13 (5): 390-6, 2008.

5- SHIMIZU S., SAITO M., KINOSHITA Y., OHMASA F., DIMITRIADIS F., et al.: Nicorandil ameliorates ischaemiareperfusion injury in the rat kidney. British Journal of Pharmacology, 163 (2): 272-82, 2011.

6- WINIARSKA K., FOCHT D., SIERAKOWSKI B., LEWANDOWSKI K., ORLOWSKA M., et al.: NADPH oxidase inhibitor, apocynin, improves renal glutathione status in Zucker diabetic fatty rats, acomparison with melatonin. Chemico-biological interactions, 218: 12-9, 2014.

7- ALTINTAS R., POLAT A., VARDI N., OGUZ F., BEYTUR A., et al.: The protective effect of Apocynin on kidney damage caused by renal ischemia reperfusion. J. Endourol., 27 (5): 617-24, 2013.

8- LIU P.G., HE S.Q., ZHANG Y.H. and WU J.: Protective effects of apocynin and allopurinol on ischemia/ reperfusion-induced liver injury in mice. World Journal of Gastroenterology, 14 (18): 2832, 2008.

9- CONNELL B.J., SALEH M.C., KHAN B.V. and SALEH T.M.: Apocynin may limit total cell death following cerebral ischemia and reperfusion by enhancing apoptosis. Food and Chemical Toxicology, 49 (12): 3063-9, 2011.

10- ALLEN-WORTHINGTON K.H., BRICE A.K., MARX J.O. and HANKENSON F.C.: Intraperitoneal Injection of Ethanol for the Euthanasia of Laboratory Mice (Mus musculus) and Rats (Rattus norvegicus). J. Am. Assoc. Lab. Anim. Sci., 54 (6): 769-78, 2015.

11-MORLEY J.E., PATRICK P. and PERRY H.M.: Evaluation of assays available to measure free testosterone. Metabolism, 51 (5): 554-9, 2002.

12- GAY V.L., MIDGLEY A.R. and NISWENDER G.D.: Patterns of gonadotropin secretion associated with ovulation. Fed. Proc., 29: 1880-7, 1970.

13- HAAVISTO A.M., PETTERSSON K., BERGENDAHL M., PERHEENTUPA A., ROSER J.F., et al.: A supersensitive immunofluorometric assay for rat luteinizing hormone. Endocrinology, 132 (4): 1687-91, 1993.
14- OHKAWA H., OHISHI N. and YAGI K.: Assay for lipid peroxides in animal tissues by thiobarbituric acid reaction. Analytical Biochemistry, 95 (2): 351-8, 1979.

15- PAGALIA D. and VALENTINE W.: Studies on the quantitative and qualitative characterization of erythrocyte glutathione peroxidase. J. Lab. Clin. Med., 70: 158-69, 1967.

16- KIM S.K., YOON Y.D., PARK Y.S., SEO J.T. and KIM J.H.: Involvement of the Fas-Fas ligand system and active caspase- 3 in abnormal apoptosis in human testes with maturation arrest and Sertoli cell-only syndrome. Fertility and Sterility, 87 (3): 547-53, 2007.

17- CHEN H., YOSHIOKA H., KIM G.S., JUNG J.E., OKAMI N., et al.: Oxidative stress in ischemic brain damage: Mechanisms of cell death and potential molecular targets for neuroprotection. Antioxidants and Redox Signaling, 14 (8): 1505-17, 2011.

18- KOSEOGLU B., YILMAZ E., CEYLAN K., UZUN E., BAYRAM I., et al.: The preotective effect of erythropoietin on testicular torsion/detorsion: An experimental study. Int. Urol. Nephrol., 41 (1): 85-91, 2009.

19- AL-OMAR F.A., NAGI M.N., ABDULGADIR M.M., AL JONI K.S. and AL-MAJED A.A.: Immediate and delayed treatments with curcumin prevents forebrain ischemiainduced neuronal damage and oxidative insult in the rat hippocampus. Neurochem. Res., 31 (5): 611-8, 2006.

20- OZDEMIR R., PARLAKPINAR H., POLAT A., COLAK C., ERMIS N., et al.: Selective endothelin A (ET A) receptor antagonist (BQ 123) reduces both myocardial infarct size and oxidant injury. Toxicology, 219: 142-9, 2006.

21- YAYI H., YEDA X., HUAXIN W., YANG W., QIAN S., et al.: Toll-like receptor 7 involves the injury in acute kidney ischemia/reperfusion of STZ-induced diabetic rats Acta Cir. Bras., 31 (7): 448-55, 2016.

22- SAHNA E., PARLAKPINAR H., OZTURK F., CIGREMIS Y. and ACET A.: The protective effects of physiological and pharmacological concentrations of melatonin on renal ischemia-reperfusion injury in rats. Urol Res., 3: 188-93, 2003.

23- CAROLINA A., MARLUCE M., CONDINO-NETO A. and XIMENES F.: The Importance of Myeloperoxidase in Apocynin-Mediated NADPH Oxidase Inhibition. Centro de Investigaçãoem Pediatria (CIPED): Faculdade de Ciências Médicas, Universidade Estadual de Campinas, CEP 13083-887, Campinas, SP, Brazil, 2012.

24- GEZGINCI-OKTAYOGLU S., SACAN O., YANARDAG R., KARATUG A. and BOLKENT S.: Exendin-4 improves hepatocyte injury by decreasing proliferation through blocking NGF/TrkA in diabetic mice. Peptides, 32: 223 $31,2011$.

25- VAN HAAFTEN R.I., HAENEN G.R., EVELO C.T. and BAST A.: Effect of vitamin E on glutathione dependent enzymes. Drug Metab. Rev., 35: 215-53, 2003.

26- SENER G., TUGTEPE H., YÜKSEL M., CETINEL S., GEDIK N., et al.: Resveratrol improves ischemia / reperfusion-induced oxidative renal injury in rats. Arch. Med. Res., 37: 822-9, 2006.

27- FUCHS Y. and STELLER H.: Programmed cell death in animal development and disease. Cell, 147 (4): 742-58, 2011. 
28- ELMORE S.: Apoptosis: A review of programmed cell death. Toxicol Pathol., 35 (4): 495-516, 2007.

29- SHAHA C., TRIPATHI R. and MISHRA D.P.: Male germ cell apoptosis: Regulation and biology. Philos Trans R Soc Lond B Biol. Sci., 365 (1546): 1501-15, 2010.

30- LUDWIG-GALEZOWSKA A.H., FLANAGAN L. and REHM M.: Apoptosis repressor with caspase recruitment domain., a multifunctional modulator of cell death. J. Cell Mol. Med., 15 (5): 1044-53, 2011.

31- GAO D., XU Z., QIAO P., LIU S., ZHANG L., et al.: Cadmium induces liver cell apoptosis through caspase$3 \mathrm{a}$ activation in purse red common carp (cyprinus carpio): PLoS One, 8 (12): 1-12, 2013.

32- PARRISH A.B., FREEL C.D. and KORNBLUTH S.: Cellular mechanisms controlling caspase activation and function. Cold Spring Harb Perspect Biol., 5 (6): 1-8, 2013.

33- KITAZUMI I. and TSUKAHARA M.: Regulation of DNA fragmentation: The role of caspases and phosphorylation. FEBS J., 278 (3): 427-41, 2011.

34- AKANDA M.R., KIM I.S., AHN D., TAE H.J., TIAN W., et al.: Geranium koreanum methanolic extract via downregulation of mapk/caspase-3 pathway. Evid. Based Complement. Alternat. Med., 8137627: 1-9, 2017.

35- POP C. and SALVESEN G.S.: Human caspases: Activation, specificity, and regulation. J. Biol. Chem., 284 (33): 21777-81, 2009.

36- HYMAN B.T. and YUAN J.: Apoptotic and non apoptotic roles of caspases in neuronal physiology and pathophysiology. Nat. Rev. Neurosci., 13 (6): 395-406, 2012.

37- KIRKLAND R.A., WINDELBORN J.A., KASPRZAK J.M. and FRANKLIN J.L.: Bax-induced pro-oxidant state is critical for cytochrome $\mathrm{c}$ release during programmed neuronal death. J. Neurosci., 22 (15): 6480-90, 2002.

38- JOVER T., TANAKA H., CALDERONE A., OGURO K., BENNETT M.V.L., et al.: Estrogen protects against global ischemia-induced neuronal death and prevents activation of apoptotic signaling cascades in the hippocampal CA1. J. Neurosci., 22: 2115-24, 2002.

39- MERGENTHALER P., DIRNAGL U. and MEISEL A.: Pathophysiology of stroke: Lessons from animal models. Metab. Brain Dis., 19: 151-67, 2004.

40- FU J., SUN H., ZHANG Y., XU W., WANG C., et al.:
Neuroprotective Effects of Luteolin Against Spinal Cord Ischemia-Reperfusion Injury by Attenuation of Oxidative Stress., Inflammation., and Apoptosis. Journal of Medicinal Food, 21 (1): 13-20, 2018.

41- LIU J., ZHU Y., CHEN S., SHEN B., YU F., et al.: Apocynin Attenuates Cobalt Chloride-Induced Pheochromocytoma Cell Apoptosis by Inhibiting P38-MAPK/ Caspase-3 Pathway. Cellular Physiology and Biochemistry, 48 (1): 208-14, 2018.

42- GIMENES R., GIMENES C., ROSA C.M., XAVIER N.P., CAMPOS D.H.S., et al.: Influence of apocynin on cardiac remodeling in rats with streptozotocin-induced diabetes mellitus. Cardiovascular Diabetology, 17 (1): 1 9, 2018.

43- CHATANI F.: Possible mechanism of testicular focal necrosis induced by human chorionic gonadotropin. J. Toxicol Sci., 31 (4): 291-303, 2006.

44- CREASY D., BUBE A., RIJK E., KANDORI H., KUWAHARA M., et al.: Proliferative and non proliferative lesions of the rat and mouse male reproductive system. Toxicol Pathol., 40 (6): 40-121, 2012.

45- AKTAS A., TUNCER M.C., Y1LD1R1M A., NERGIZ Y. and AKKUS M.: Protective Effects of Melatonin on Testicular Torsion and Detorsion Damage in SpragueDawley Rats. Int. J. Morphol., 29 (1): 7-15, 2011.

46- AITKEN R.J. and ROMAN S.D.: Antioxidant systems and oxidative stress in the testes. Oxidative Medicine and Cellular Longevity, 1 (1): 15-24, 2008.

47- WALKER W.H. and CHENG J.: FSH and testosterone signaling in Sertoli cells. Reproduction, 130 (1): 15-28, 2005.

48- AHMED A.I., LASHEEN N.N. and EL-ZAWAHRY K.M.: Ginkgo Biloba Ameliorates Subfertility Induced by Testicular Ischemia/Reperfusion Injury in Adult Wistar Rats: A Possible New Mitochondrial Mechanism. Oxidative Medicine and Cellular Longevity, 2016.

49- O'SHAUGHNESSY P.J., MORRIS I.D. and BAKER P.J.: Leydig cell re-generation and expression of cell signaling molecules in the germ cell-free testis. Reproduction, 135 (6): 851-8, 2008.

50- GONG Y.G., WANG Y.Q., GU M., FENG M.M., ZHANG W., et al.: Deprival of testicular innervation induces apoptosis of Leydig cells. Biochemical and Biophysical Research Communications, 382 (1): 165-70, 2009. 


\section{دراسة تآثير الآبوسينين على التلف الناتج عن نقص التغذية الدموية للخفصية

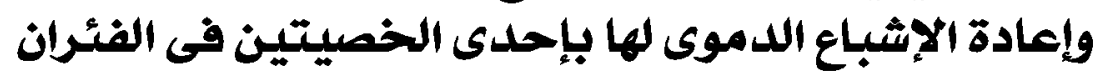

الهدف من البحث: يهدف البحث إلى دراسة تآتير الآبوسينين على التلف الناتج عن نقص التفذية الدموية للخمية وإعادة الإشباع الدمهى ل الها بإحدى الخصيتين فى الفئران.

طرق البحث: تم إجراء البحث على (·r فأراً من ذكود الفئران البيضاء تم تقسيمها إلى ثلاثة مجموعات كل مجموعة تحتوى على ·ـ الفئران):

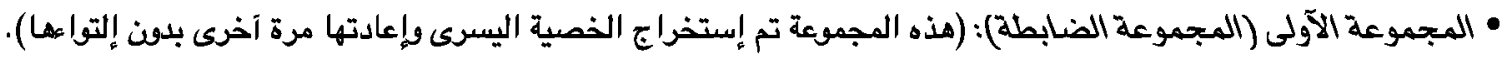

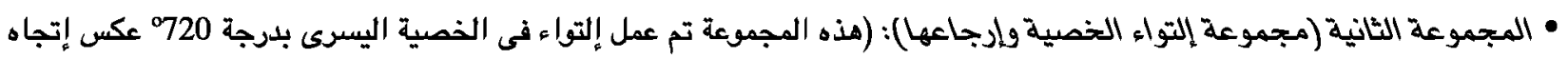

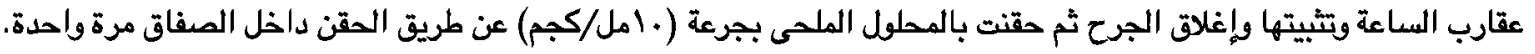

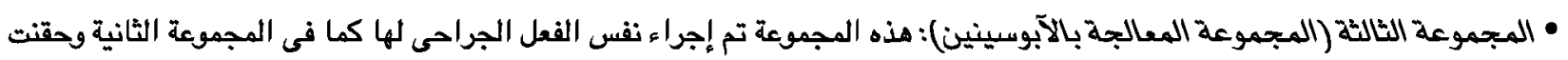

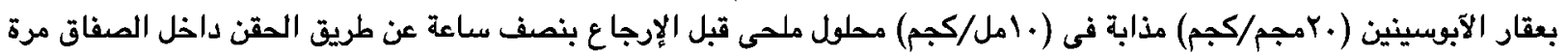
واحدة.

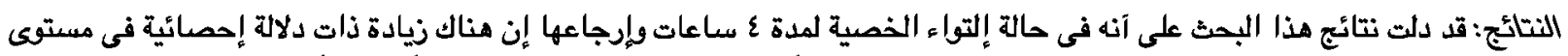

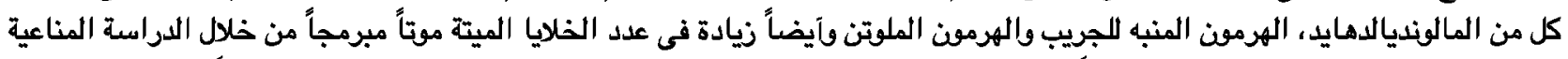

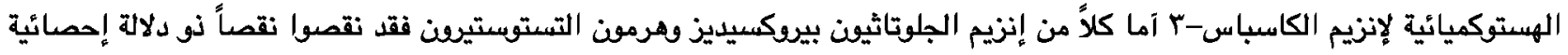

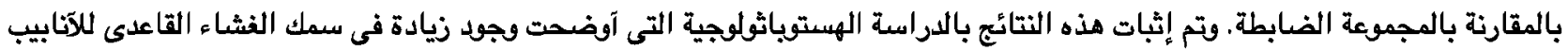

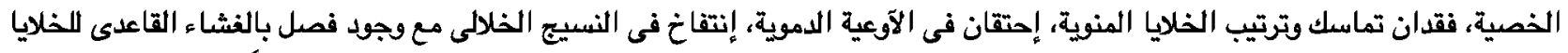

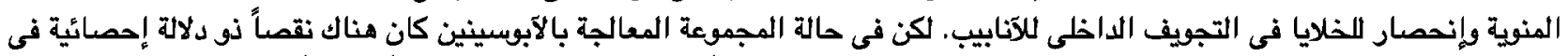

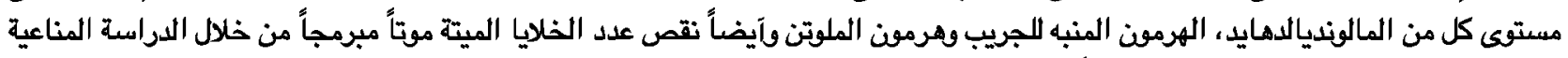

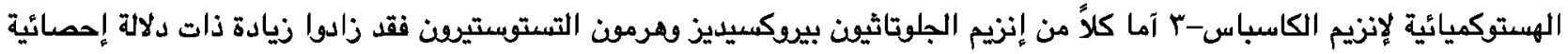

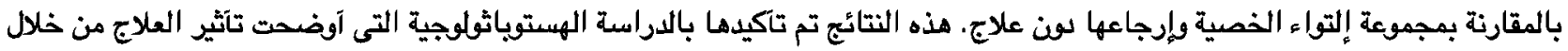

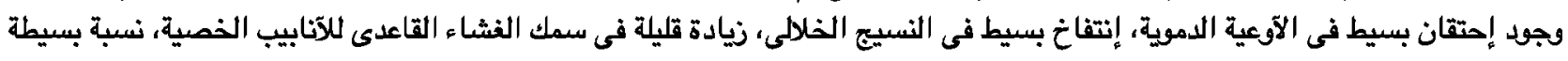
من فقدان تماسك وترتيب الخلايا المنوية.

الإستستاج: نستتج آن الآبوسينين يلعب دوراً فعالاً فى حالات إنقاص تدفق الدم الموضعى ثم إعادة الإشباع الدمهى وإن إستخدامه يقدم 